\title{
EFFECT OF SILICA COATING IN ACRYLIC ARTIFICIAL TEETH ON SURFACE ROUGHNESS, CONTACT ANGLE, AND GROWTH OF STREPTOCOCCUS MUTANS
}

Adella Syvia Maharani*, Pramudya Aditama*, Murti Indrastuti*, Suparyono Saleh*

`Prosthodontics Department, Faculty of Dentistry, Universitas Gadjah Mada, Yogyakarta

Correspondence: adellasyviamaharani@ugm.ac.id

Keywords:
Acrylic resin artificial teeth,
Contact angle, Silica
coating, Streptococcus
mutans

INTRODUCTION

Removable dentures are currently the most frequently treatment preferred by patients due to several considerations, especially if a patient has contraindications and is not willing to undergo tooth extraction for fixed dental bridge. The components of removable dentures include denture bases, retainer, and artificial teeth. Artificial teeth are used to replace the lost natural teeth. In fact, artificial teeth shall be selected by considering the size, shape, surface texture, color, and material. ${ }^{1}$

The material for artificial teeth can be either acrylic resin and porcelain. The ideal requirements for the material of artificial teeth are having good esthetics, being able to be attached to denture base, having low density, and being strong and resistant to staining. Acrylic resin is the most widely used material for artificial teeth until now. ${ }^{2}$ Some of the strength of acrylic resin artificial teeth are good adjustability, good chemical bonding to denture base, lack of clicking sound, light, and affordable. On the other hand, the weaknesses of acrylic resin artificial teeth are it is easy for abrasion, color change, and bacterial adhesion to take place. ${ }^{3}$

Denture material should have a smooth surface to prevent the adhesion of microorganisms. These microorganisms could cause the development of both carious lesions and periodontal diseases around the denture and oral cavity. In fact, different dental 
materials have differences in terms of bacterial adhesion to the surface of these materials; it is determined by surface roughness and contact angle measurement. ${ }^{4}$ One of the microorganisms that are commonly attached to dentures is

Streptococcus mutans. Streptococcus mutans are able to produce extracellular polysaccharides to attach to a surface. The extracellular polysaccharides consist of glucose polymers which cause plaque matrix with gelatin-like consistency, causing bacteria to be attached to one another. $^{5}$

Acrylic resin artificial teeth have a good attachment to acrylic resin denture bases, but the potential for bacterial attachment to acrylic resin artificial teeth has not been widely studied. Acrylic resin artificial teeth are in direct contact with the remaining natural teeth and the oral cavity. Plaque formation in dentures may contribute to the development of caries in the

\section{METHODS}

Disk-shaped acrylic resin artificial teeth were made with a diameter of $10 \mathrm{~mm}$ and a thickness of $2 \mathrm{~mm}$ using a bur. Finishing and polishing were done after the making of the research samples was finished. The samples were then divided into two groups, namely group I without silica coating (16 samples) and group II with silica coating (16 samples). A $2 \%$ silica coating material was made by silica nanoparticles were placed on a beaker and weighed using digital scale to get $2 \mathrm{~g}$ of it. Ethanol solution as solvent was measured using a measuring cup to get $100 \mathrm{ml}$ of it, then poured into the beaker containing silica. After that, the mixture was stirred using a magnetic stirrer until homogeneous solution was obtained. Silica coating was applied using dipcoating method, by firstly applying silane remaining natural teeth and gingival inflammation in the area around the denture. ${ }^{4}$ It is necessary to perform a treatment on the surface of acrylic resin artificial teeth in order to reduce bacterial adhesion. Silica is widely applied as an additive and modification of dental materials. Modification of the surface of dental materials using silica coating can maximize the finishing and polishing processes of the materials. In fact, maximum polishing process could prevent bacterial adhesion to the surface of dental material. Silica coating also can modify hydrophobic materials, such as acrylic resin so that the surface can be hydrophilic, thus preventing the adhesion of microbes to the surface of dental materials. ${ }^{6}$ The objective of this study was to determine the effect of silica coating in acrylic resin artificial teeth on surface roughness, contact angle measurement, and the growth of Streptococcus mutans.

coupling agent on the acrylic resin artificial teeth samples. The acrylic resin artificial teeth samples were then coated by dip-coating method into the silica coating solution, and then heated in an oven with a temperature of $70^{\circ} \mathrm{C}$ for 10 minutes.

The surface roughness of the acrylic resin artificial teeth samples was measured using a surface roughness measuring instrument. One droplet aquabides $(4 \mu \mathrm{L})$ was dropped at an angle of $90^{\circ}$ on the acrylic resin artificial teeth samples, then photos of the droplets was taking using a camera digital. The angle formed between the droplet surface and the surface of the acrylic resin denture sample was calculated as the surface contact angle. 
Bacterial growth test was carried out using Streptococcus mutans obtained from the Research Laboratory of the Faculty of Dentistry, Universitas Gadjah Mada. The bacterial suspension was prepared according to the standard of $0.5 \mathrm{Mc}$ Farland $(1.5 \times 108 \mathrm{CFU} / \mathrm{ml})$. Streptococcus mutans colonies were firstly cultured into $\mathrm{BHI}$ agar and incubated at $37^{\circ} \mathrm{C}$ for 24 hours. After 24 hours of incubation, Streptococcus mutans were taken using 1 ose needle and put into $10 \mathrm{ml}$ sterile distilled water, followed by dilution to comply with 0.5 McFarland standard $\left(1.5 \times 10^{8}\right.$ $\mathrm{CFU} / \mathrm{ml})$. The growth of Streptococcus mutans was measured by pour plate method using Streptococcus mutans which had been diluted to a concentration of $1.5 \times 10^{8} \mathrm{CFU} / \mathrm{ml}$. A total of 32 samples of disk-shaped acrylic resin artificial teeth with a diameter of $5 \mathrm{~mm}$ and a thickness of $2 \mathrm{~mm}$ were immersed in sterile distilled water for 48 hours, then sterilized using an autoclave for 18 minutes at $121^{\circ} \mathrm{C}$. After that, the acrylic

\section{RESULTS}

Group I contained the research samples which were not silica coated, while group II contained silica-coated research samples. The results showed that the mean and standard deviation of the surface roughness in group I $(0.29 \pm 0.08$ $\mu \mathrm{m})$ were higher than those in group II $(0.17 \pm 0.05 \mu \mathrm{m})$. The contact angle measurement in group I $\left(79,49 \pm 10,88^{\circ}\right)$ were higher than group II $\left(34,77 \pm 0,05^{\circ}\right)$. The growth of $S$. mutans in group I were also higher resin artificial teeth samples were immersed in artificial saliva for 1 hour to form pellicle. Afterwards, the samples of acrylic resin artificial teeth were taken and put into $10 \mathrm{ml}$ Streptococcus mutans bacterial suspension for 24 hours at $37^{\circ} \mathrm{C}$ in a test tube. The samples were taken again and put into a conical tube containing $10 \mathrm{ml}$ sterile distilled water and vibrated using vortex for 1 minute to remove the bacteria attached to the samples. The samples were diluted until $10^{-3}$ to ease the counting of the bacteria. A total of $0.01 \mathrm{ml}$ suspension was taken into the $\mathrm{BHI}$ agar on a petri dish, spread using a spreader, and incubated for 48 hours at $37^{\circ} \mathrm{C}$. Bacteria were counted by counting the number of Streptococcus mutans that grew on the petri dishes using a colony counter.

The data analysis used T-test dan correlation test to determine the effect of silica coating in acrylic resin artificial teeth on surface roughness, contact angle measurement, and the growth of Streptococcus mutans.
(32.28 $\pm 3.75 \mathrm{CFU} / \mathrm{ml})$ than that in group II $(24.83 \pm 3.47 \mathrm{CFU} / \mathrm{ml})$. The results of the T-test on surface roughness, contact angle measurement, and the growth of $S$. mutans showed a significant difference $(p<0.05)$ between group I and group II. Descriptive data and T-test on surface roughness, contact angle measurement, and the growth of $S$. mutans were presented in Table I.

Table I. Mean and standard deviation $(\bar{x} \pm \mathrm{SD})$, and T-test of surface roughness, contact angle measurement, and growth of $S$. mutans in acrylic resin artificial teeth

\begin{tabular}{lll}
\hline Group I & Group II & T-test \\
\hline
\end{tabular}




\begin{tabular}{lcccc}
\hline & & $\mathbf{t}$ & $\mathbf{p}$ \\
\hline $\begin{array}{l}\text { Surface Roughness } \\
(\mu \mathrm{m})\end{array}$ & $0.29 \pm 0.08$ & $0.17 \pm 0.05$ & 4.74 & $0.00^{*}$ \\
\hline $\begin{array}{l}\text { Contact angle } \\
\text { measurement (o) }\end{array}$ & $79,49 \pm 10,88$ & $34,77 \pm 0,05$ & 11,98 & $0,00^{*}$ \\
\hline $\begin{array}{l}\text { Growth of S.mutans } \\
(\mathrm{CFU} / \mathrm{ml})\end{array}$ & $32.28 \pm 3.75$ & $24.83 \pm 3.47$ & 6.16 & $0.00^{*}$ \\
\hline
\end{tabular}

${ }^{*}$ significant $p<0.05$

The results of the correlation test

correlation coefficient $(r)$ of 0.97 . These (Table II) between surface roughness - the growth of $S$. mutans in acrylic resin artificial teeth showed a correlation coefficient ( $r$ ) of 0.91 ; and the correlation test between contact angle measurement - the growth of $S$. mutans in acrylic resin artificial teeth showed a indicate that there was a significant and strong correlation between surface roughness, contact angle measurement, the growth of $S$. mutans. The positive correlation indicates that the higher the surface roughness and contact angle value, the higher the growth of $S$. mutans.

Table II. Results of correlation test between surface roughness, contact angle measurement, and growth of S.mutans in acrylic resin artificial teeth

\begin{tabular}{|c|c|c|}
\hline & $\mathbf{r}$ & $\mathbf{p}$ \\
\hline Surface Roughness & \multirow{2}{*}{0.91} & \multirow{2}{*}{0.00} \\
\hline Growth of S.mutans & & \\
\hline Contact Angle Measurement & \multirow{2}{*}{0.97} & \multirow{2}{*}{0.00} \\
\hline Growth of S.mutans & & \\
\hline
\end{tabular}

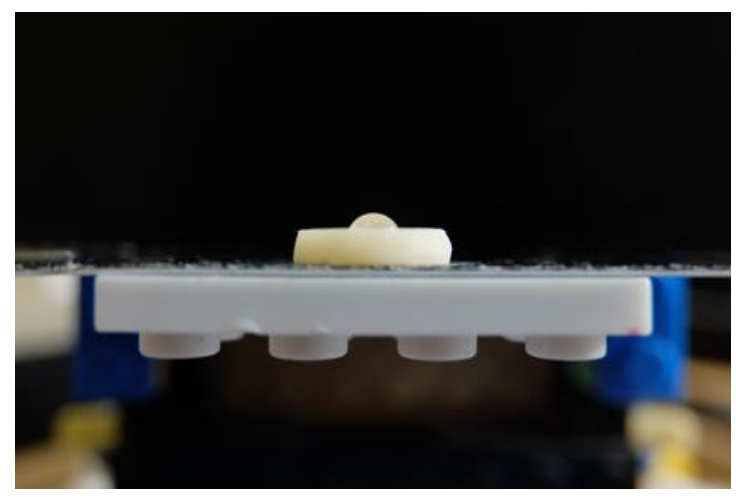

Figure 1. Contact angle measurement of Group I 


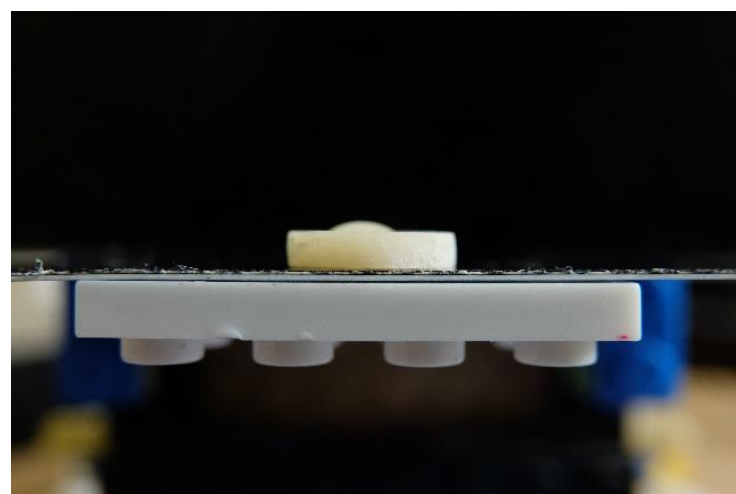

Figure 2. Contact angle measurement of Group II

\section{DISCUSSION}

Acrylic resin properties such as porosity, hydrophobicity, hydrophilicity, and surface roughness have been reported to influence the attachment of microorganisms to denture materials. ${ }^{7}$ Bacterial adhesion in acrylic resin is affected by various physico-chemical properties of bacterial and material surfaces. Physico-chemical properties are given by environmental conditions of bacteria and surface properties of materials (surface roughness, hydrophobicity, and charge). There is a reversible interaction between the bacterial cell surface and the material surface. Bacterial adhesion in acrylic resin denture base is governed by electrostatic, hydrophobic effects, and contact interactions. The relationship between surface roughness and bacterial growth showed that higher surface roughness value indicates higher growth of Streptococcus mutans. The silica-coated surfaces (Group II) had lower surface roughness value because silica nanoparticles could fill the empty gaps due to the finishing process on the surface of acrylic resin artificial teeth. ${ }^{8}$ Modifying surface properties with silica coating has more advantages. Silica nanoparticles dissolved in ethanol solution could also dissolve the rough surface of acrylic resin, making the surface of acrylic resin smoother. ${ }^{9,10}$

Higher bacterial adherence on rough surfaces occurs because the presence of empty gaps, pits, and grooves that can reduce the influence of shear forces on the bacteria initially attaching to the surface. Streptococcus mutans have a tendency to attach to tooth surface and rough surface. ${ }^{10}$ On the rough surface of artificial teeth, it is easier for Streptococcus mutans with hydrophilic properties to be attached to acrylic resins with hydrophobic properties, making it easier for the bacteria to colonize and grow. ${ }^{5}$

The amount of bacteria adherent to a surfaces can also be determined by some surface characteristics, such as hydrophobicity and hydrophilicity. ${ }^{11}$ Silica has intrinsic hydrophilicity characteristic because of its surface hydroxyl groups. Silica be used to coat and modify hydrophobic materials such as acrylic resin to have a hydrophilic surface. ${ }^{6}$ This hydrophilic surface modification is a potentially useful to manage microbial development, such as Streptococcus mutans. Silica coating can modify hydrophobic materials, such as acrylic resin so that the surface can be hydrophilic, 
then prevent the adhesion of microbes to the surface of acrylic resin. 6,7

The surface of dental materials, like artificial teeth acrylic resin; and the liquid can show a contact angle. Contact angle is calculated between the surface of the artificial teeth arcylic resin and the surface of the liquid. It can determine the hydrophobic and hydrophilic characteristics of the surface. The surface contact angle with a size $>90^{\circ}$ has hydrophobic characteristics, while the surface contact angle with a size $<90^{\circ}$ has hydrophilic characteristics. ${ }^{12,13}$

Silica coating in this study is used as hydrophilic treatment, that can make the surface of acrylic resin artificial teeth become hydrophilic. The results of this present study showed that the lower contact angle measurement (hydrophilic chcracteristics) had

\section{CONCLUSIONS}

There is an effect of silica coating on the surface roughness, contact angle measurement, and the growth of Streptococcus mutans in acrylic resin artificial teeth. The higher surface roughness, the higher growth of

\section{ACKNOWLEDGEMENT}

I would like to thank Research Grant from Dana Masyarakat FKG UGM in the year of 2018 and

\section{REFERENCES}

1. Nallaswamy, D., Textbook of Prosthodontics, Jaypee Brothers, India. 2017.

2. Nakhaei, M., Dasthi, H., Barazandeh, R., Shear Bond Strength of Acrylic Denture Teeth to PMMA and Polyamide Denture Base Materials., J of Dent Material and Technique, 2018; 7(1):19-24.

3. Reis, K.R., Bonfante, G., Pegoraro, F., In vitro wear resistance of three types of the lower Streptococcus mutans adherence; the higher contact angle measurement (hydrophobic characteristics) had the higher Streotococcus mutans adherence. The capability of initial microbial adhesion to denture materials surface is influenced by surface wettability of materials, that measured by evaluating contact angle measurement. ${ }^{13}$ The important factors affecting adherence of Stretococcus mutans to acrylic resin artificial teeth is hydrophobic interaction. Hydrophobic interaction occurs between cell surface and the substratum that would enable the cell to overcome the repulsive forces active within a certain distance from the substratum surface. The surface of a Streptococcus mutans is hydrophobic. So, hydrophilic surface modification using silica coating can be an effective method of inhibiting adherence of Streptococcus mutans. ${ }^{4,14}$

Streptococcus mutans in acrylic resin artificial teeth; and also the higher contact angle measurement, the higher growth of Streptococcus mutans in acrylic resin artificial teeth.

2019. This work would not have been possible without the financial support from FKG UGM.

polymethyl methacrylate denture teeth. $\mathrm{J}$ Ap Oral Sci, 2008; 16(3):176-180.

4. Hahnel, S., Rosentrit,M., Handel, Adhesion of Streptococcus mutans NCTC 10449 to artificial teeth: An in vitro study. J of Prost Dent, 2008; 100(4),309-315.

5. Samarayanake,L., Essential Microbiology for Dentistry, 4th ed., London : Churchill Livingstone. 2012.

6. Akiba, N., Azuma, A., Minakuchi, S., Hydrophilic surface modification of acrylic 
denture base material by silica coating and its influence on Candida albicans adherence.J.Med.Dent.Sci, 2012; 59:1-7.

7. Vitalariu, A., Diaconu, D., Tatariuc, D., Effects of Surface Characteristics of the Acrylic Resins on the Bacterial Colonization. Revista de Chimie Bucharest Original Edition. 2015; 1-5

8. Yodmongkol, S., Chantaracindawong, R., Thaweboon, S., Films on Candida albicans Adhesion and the Surface and Physical Properties of Acrylic Resin Denture Base Material. The J Prost Dent., 2014, 1-6.

9. Dantas, L., Neto, J.P., Dantas, T.S., Bacterial Adhesion and Surface Roughness for Different Clinical Techniques for Acrylic Polymethyl Methacrylate. Int J of Dentistry. 2016; 1-6.

10. Silvia, S., Djais, A., Soekanto, A.S., The Amount of Streptococcus mutans Biofilm on Metal, Acrylic Resin, and Valplast Denture Bases. J of Int Dent and Med Research. 2018; 11(3):899-905.

11. Yoshizaki, T., Akiba, N., Inokoshi, M., Hydrophilic Nano-Silica Coating Agents With Platinum And Diamond Nanoparticles For Denture Base Materials. Dent Mat J. 2017. 1-7.

12. Kumar, S.S., Hiremath, S.S., Ramachadnran, B., Effect of Surface Finish on Wettability and Bacterial Adhesion of Micromachined Biomaterials. Biotribilogy. 2019. 18:1-12.

13. Yulianto, H.D., K., Rinastiti,M., Contact Angle Measurement Of Dental Restorative Materials By Drop Profile Image Analysis. 2014. Jurnal Tekno Sains. 3(2):112-119.

14. Hamadi, F., Latrache, H., Comparison Of Contact Angle Measurement And Microbial Adhesion To Solvents For Assaying Electron Donor-Electron Acceptor (AcidBase) Properties Of Bacterial Surface. Colloids and Surfaces B: Biointerfaces. 65:134-139. 